\title{
Klasik Bir Edebî Romanda Nesne Adlarında Kullanılan Göstergelerin Yorumlanması ${ }^{1}$ Selim YILMAZ ${ }^{2}$, Mine KILIÇ
}

\section{$\ddot{\mathbf{O} z}$}

Anahtar Sözcükler

$\mathrm{Bu}$ makalede klasik bir edebî romanda geçen nesne adlarında kullanılan dilsel göstergeler dilbilimsel açıdan yorumlanmaya çalışılacaktır. Araştırmanın bütüncesi 19. yüzyıl Fransız Edebiyatı yazarlarından Emile Zola'nın "Claude'un İtirafları" başlıklı klasik eseridir. Tek bir yazar ve onun sadece bir romanı üzerinde çalışılacağından bu makale uygulamalı dilbilim alanında bir durum çalışması olarak değerlendirilmelidir, dolayısıyla sözce ve gösterge yorumlarında genelleştirici değerlendirmelerden uzak durulacaktır. Burada temel amaç, edebî romanda nesne adlarının sınıflandırılması, dilsel göstergeler aracılığıyla yorumlanması ve böylece nesne ile insan zihni, bilinci ve ruhsal durumu arasındaki bağlantının irdelenmesidir. Çalışmanın kuramsal altyapısını Sassure'ün temelini attığı Genel Dilbilimin omurgası olan "dil-söz" ikili terimi bağlamında "Gösterge Dizgesi” ve "Sözceleme" kuramı oluştururken, metodoloji olarak da günümüz dilbiliminde kullanılan "Söylem Çözümlemesi” yöntemi izlenecektir. Metindilbilimi alanına kısa bir giriş yaptıktan sonra ilgili romandan seçilen çeşitli sözce örnekleri nesne kullanımı bakımından sinıflandırılacak ve bu sözcelerde nesneye bağlanarak ona nitelik kazandıran farklı dilsel göstergelerin değer ve işlevleri mercek altına alınacaktır.

\section{Interpretation of Signs Used for Object Names in a Classical Literary Novel}

\begin{abstract}
In this article, linguistic signs used for object names in a classical literary novel will be tried to interpret linguistically. The corpus of the study is Claude's Confessions by Emile Zola. This article should be considered as a case study in the field of applied linguistics. The main purpose here is to classify the object names in the literary novel, to interpret them through linguistic signs and thus to examine the connection between the object and the human mind, consciousness short introduction to textlinguistics, various utterances selected from the related novel will be classified in terms of object usage, and and spiritual state. The "Sign System" and "Enunciation" theory in the context of the dichotomy "language-speech" by Saussure, constitute the theoretical background of the study. After a in these utterances, the values and functions of different linguistic signs that attach to the object and give it quality will be scrutinized.
\end{abstract}

Keywords

linguistics

sign

object

utterance

enunciation

Emile Zola

About Article

Received: 30.03.2021

Accepted: 10.06.2021

Doi:

10.20304/humanitas.906617

\footnotetext{
${ }^{1}$ Bu çalışma Marmara Üniversitesi BAP Birimi tarafından desteklenen Çok Disiplinli Uluslararası Sosyal B Tipi Projesi kapsamına girer. Projenin konusu: "Batı Dilbilimi Kuram ve Yöntemleri Işı̆̆ında Türkçenin Konuşma Dili Yapısı ve İşleyişi (Pragmatik Yaklaşımlar).” Yürütücü: Selim Yılmaz, Proje Kodu: SOS-B-071015-0490. Kurumumuza buradan teşekkür ediyoruz.

${ }^{2}$ Prof. Dr., Marmara Üniversitesi, Fen-Edebiyat Fakültesi, Fransız Dili ve Edebiyatı Bölümü, İstanbul/Türkiye, selimy26@gmail.com, ORCID: 0000-0002-9028-4080

${ }^{3}$ Dr., Bağımsız bilim insanı, İstanbul/Türkiye, minekilic@ windowslive.com, ORCID: 0000-0002-8328-0970
} 


\section{Giriş}

Genel kuramsal çerçevesini Dilbilim ve Göstergebilim yaklaşımının oluşturduğu bu çalışmada öncelikle Dilbilim alanıyla kısa bir giriş yapmak yerinde olacaktır. Dilbilim, 20. yüzyıldan itibaren kendisine önemli bir çalışma ortamı bulmuş, dilin çeşitli sahalarında çalışmalar yapmış ve yeni dilbilgisel kurallar ortaya çıkarmıştır. Dilbilimin çalışma sahaları içinde yer alan Göstergebilim, Edimbilim ve Metindilbilimi bu çalışma sırasında göz önünde bulundurularak değerlendirilmesi gereken alanlar olarak görülmektedir.

Bu çalışmada olduğu gibi, belirli bir metin üzerinde sözce ve gösterge analizi yapılan bir araştırmada, Göstergebilim alanını kısaca hatırlamakta ve hatırlatmakta mutlaka surette bir fayda vardır. Göstergebilim, en genel ve bilinen tanımıyla göstergeleri ve gösterge dizgelerini inceleyen bilim dalıdır. Gösterge "genel olarak bir başka şeyin yerini alabilecek nitelikte olduğundan kendi dışında bir şey gösteren her türlü nesne, varlık ya da olgu”dur. Sonuçta göstergebilim sadece dilsel göstergeleri değil, temsilî olan ve anlamlı bir bütün oluşturan her şeyi inceler. Göstergebilimin kurucuları olarak anabileceğimiz Amerikalı filozof Peirce ve İsviçreli dilbilimci Saussure'ün birbirini destekleyen çalışmaları neticesinde dilde "Söz" (fr. parole) adı verilen bireysel kullanımlardan ziyade genel "Dil" kavramıyla toplumsal iletişim sistemi üzerinde durulmuş, göstergebilimsel dizgeler dâhilinde sosyal ve kültürel olguların işlevleri üzerine odaklanılmıştır. Saussure'ün “Gösteren - Gösterilen” dikotomisinden oluşan "Gösterge dizgesi" ile ilgili kuramını benzetme - karşılaştırma yaklaşımı çerçevesinde “satranç analojisi” ile açıklanabilir. Gösterge dizgesini bir şemayla netleştirelim:

\section{Gösterge}

Dizgesi

Gösteren

Gösterilen

Şekil 1. Saussure'ün gösterge dizgesi

Diğer yandan, dil sistematiğinin birinci basamağındaki dilin devingen ya da dinamik yapısı, yani “devingenliği” açısından satranç oyununun kuralları olarak düşünülürse, öncelikle sistemin kurallarını bilmenin gerekliliği açıktır. İkinci basmağı "Dil, Dil yetisi, Edinç (Kompetans), Sözceleme” kavramları, yani kafanızda satranç kuralları dâhilinde hamlenizi kurmak oluştururken, üçüncü basamakta ise "Söz, Söylem, Edim (Performans)" kavramları 
Yılmaz, S. ve Kılı̧̧, M. (2021). Klasik bir edebî romanda nesne adlarında kullanılan göstergelerin yorumlanması. Humanitas, 9(18), 342-365.

bakımından söz zincirini meydana getiren sözceler serisi devreye girmektedir. Anlatmaya çalıştığımız bu üç basamaklı sistemi bir şemayla gösterelim:

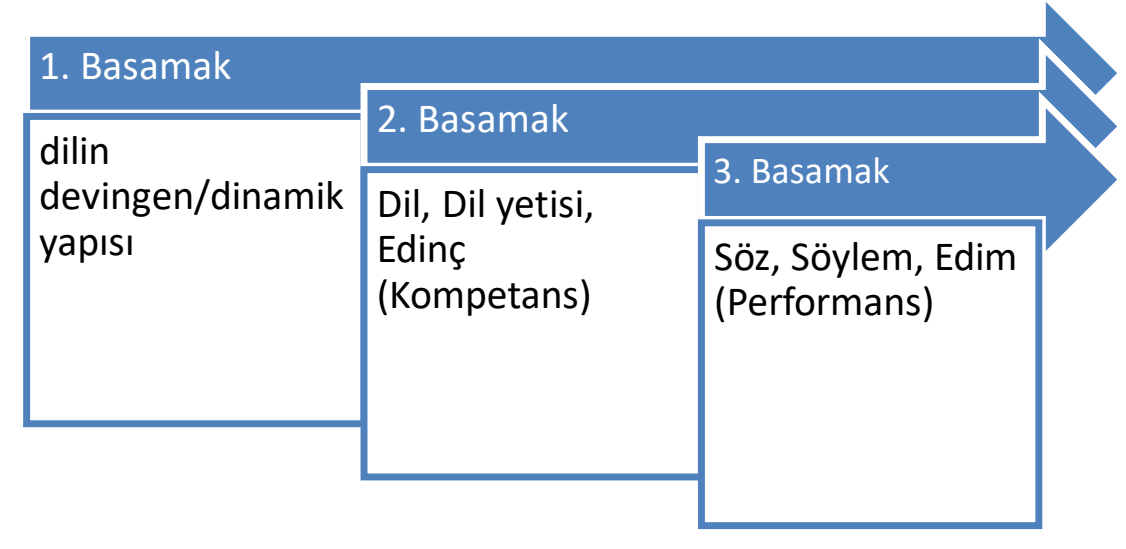

Şekil 2. Dil sistematiği

Edebî metin incelemelerinde "Sözce" terimini kullanırken tam manasılala ne kastedildiği mutlaka önceden açıklığa kavuşturulmalıdır. Burada "sözce" terimiyle anlatılan, sözlü ya da yazılı ifadede iki durak (yazı dilinde virgül) arasında kalan söz zinciri parçasıdır. Bu parça her zaman bir cümle olarak algılanmamalı, eksiltili yapılar, hatta tek bir sözcüğün de bağlama göre sözce olabileceği düşünülmelidir. Yani her adımın birbirine bağlı olduğu satrançta olduğu gibi hamleyi zamanında uygun bağlantıları düşünerek gerçekleştirmek gerekmektedir. Kıran'ın (1999) tanımlamasına göre, bir sözcenin gerçek amacı, yani edimbilimsel değeri, ancak sözceleme (sözceleri belli bir bağlam ve durum içinde gerçekleştirme) durumunun bilinmesiyle anlaşılır. Sözceleme ise yazılı dil ve sözlü dil için farklı incelemeler gerektirmektedir. Sözcelemeye ilişkin bu durumu şu şekilde bir şemayla gösterebiliriz:

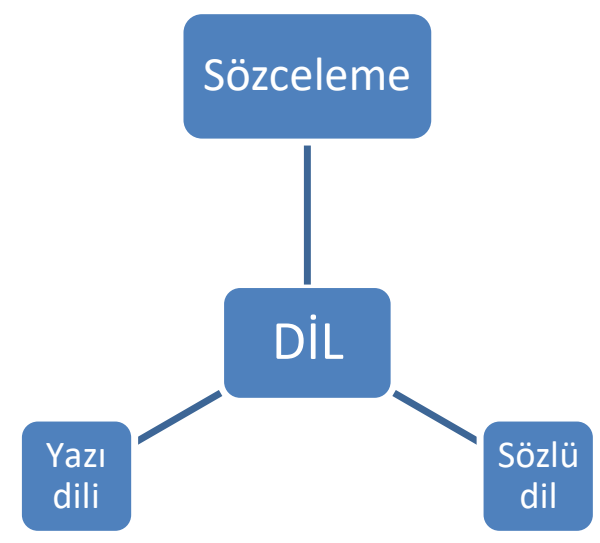

Şekil 3. Sözceleme kuramı ve dil 
Yılmaz, S. ve Kılı̧̣, M. (2021). Klasik bir edebî romanda nesne adlarında kullanılan göstergelerin yorumlanması. Humanitas, 9(18), 342-365.

Üzerinde çalışılan metin türü ne olursa olsun, sözce analizlerinde Sözceleme kuramı mutlaka göz önünde bulundurulmalıdır. Bu bakımdan Sözceleme kuramı çerçevesinde bakıldığında, sözlü dilin yapısı ve işleyişinin dünya dillerinin genel yapısına 1şı tuttuğu bilinen bir gerçektir. Sözlü dilde parçalarüstü yapılar, yani sese ilişkin bürünsel/prozodik unsurlar da sözceleri değerlendirmede özel önem arz etmektedir. Genel olarak "Dil" ve Gösterge" kavramlarına bu açıdan bakıldığında, Göstergebilim alanının Edimbilimin yanı sıra Dilbilimin dallarından Anlambilim, Biçimbilim ve Sözdizim gibi alanları içine alan bir bilim dalı olduğunu söylemek mümkündür. Bu durumu aşağıdaki şekille somutlaştıralım:

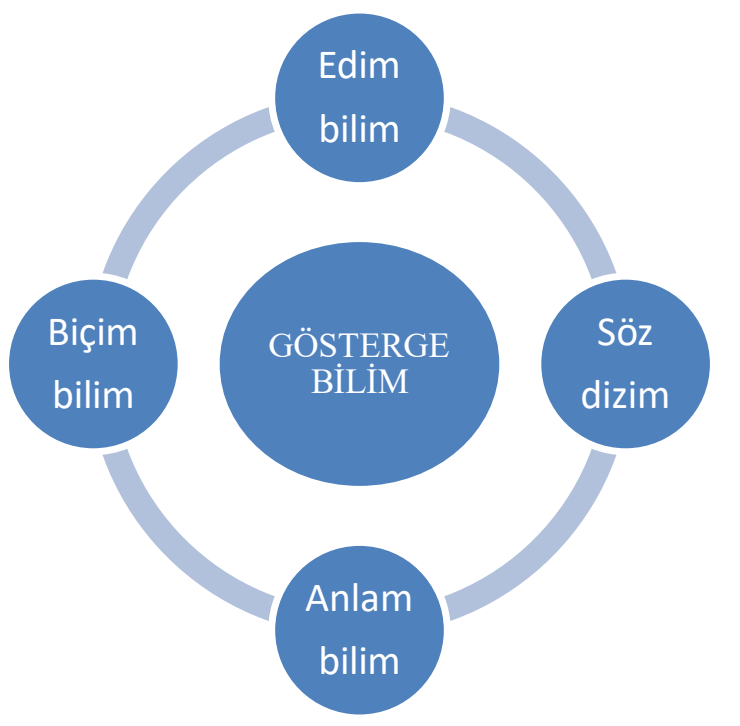

Şekil 4. Göstergebilim ve dilbilimin dalları

Çalışmaya yaklaşım olarak ışık tutacağını düşünerek Edimbilim alanına da kısaca değinmekte yarar vardır. Edimbilim gösterge dizgesinin kullanıldığı metinde dil - kültür iliş̧kisi bakımından incelemeyi amaçlar. Burada hem metiniçi hem de metindışı bağlam göz önünde bulundurulur. Yani anlambilimin aksine daha çok bağlam bağımlı anlamla uğraşır. Kansu-Yetkiner (2009) “Çeviribilim-Edimbilim İlişkisi Üzerine” adlı eserinde, Dilbilim kuralları çerçevesinde dilin toplumsal uygulamaları, dil felsefesi, mantık, ruhbilim, göstergebilim gibi birçok alan Edimbilim içinde bütünleşerek bir yoruma ulaştığını ifade eder. Aynı eserde edimbilimsel yaklaşımlarla ilgili değerlendirmesi şu şekildedir: "Günümüzde ise edimbilimsel yaklaşımlar bir tarafta bilişsel temellerde yükselip dilbilimsel ve kültürel kurallardan etkilenirken, diğer tarafta dilin sosyal ve etkileşimsel boyutlarının altını çizen bir zemin yaratmaktadır.” Kısaca Edimbilim, sosyal ve etkileşimsel boyutta söylem çözümlemesi çalışmalarında bağlamın altını çizerek dilbilim incelemeleri şeklinde ön plana çıkar. Bağlamı farklı boyutlarda değerlendiren edimbilimciler, eşmetinsel bağlam, varoluşsal bağlam, durum bağlam, eylem bağlam ve ruhbilimsel bağlam üzerinde dururlar. 
Yılmaz, S. ve Kılı̧̧, M. (2021). Klasik bir edebî romanda nesne adlarında kullanılan göstergelerin yorumlanması. Humanitas, 9(18), 342-365.

Son olarak Metindilbilimi alanından bahsetmeden geçmemek gerekir. Metindilbilimi herhangi bir konunun dilsel bütünlük içerisinde ele alınması sonucu oluşan, bir bildirişim görevi üstlenen yani metin değeri taşıyan yazıları inceleme alanı olarak seçer ve kendine özgü araştırma yöntemleri geliştirir. Metindilbilimi temelde nesnesini yedi (7) ölçüte göre kendine konu edinir. Bunlar bağgaşıklık ve tutarlılık olgularının yanı sıra niyetlilik, metin içi ilişki, bilgi vericilik, benimsenirlik ve durumsallıktır. Geleneksel dil bilgisinden ve metin çözümleme biçimlerinden farklılaşan bir yaklaşımı olan Metindilbilimi çalışmaları diğer birçok alanla iş birliği içinde yürütülür. Bu nedenle, geleneksel içerik çözümlemesinden ayrılır. Kısacası ele aldığı metni nitelik açısından çözümlemeyi amaçlar. Genel kabul gören anlayış, yazılı metinler ve sözlü ürünlerin, Metindilbilimi alanı ile Söylem Çözümlemesi için ortak bir çalışma alanı oluşturduğudur. Özkan'ın (2004) genel değerlendirmesine göre, her ne kadar Metindilbilimi daha çok yazılı metinleri, Söylem Çözümlemesi ise sözlü ürünleri kendisine nesne olarak seçmiş olsa da, Söylem Çözümlemesi’nin Metindilbilimi için birtakım bakış açılarıyla yöntem belirleyici özellikler taşıdığı görülür. İlk olarak 1955 yılında Coseriu'un kullandığı "Metindilbilimi” terimi ülkemizde de son zamanlarda Dilbilim alanında çalışan araştırmacıların gündemindedir.

Her dilin kendine özgü olanaklarına bağlı özel durumlarının varlığını kabul eden Metindilbilim, bu durumlara bağlı olarak bir metindeki bilginin açık olarak alıcıya aktarılabileceği gibi, örtük bir biçimde de aktarılabileceği noktasından hareket eder. $\mathrm{Bu}$ hareket noktasından baktığımızda, metinlerin iletişimsel işlevlerini gerçekleştirmesi için metin yapısının, metnin taşıdığı iletişimsel işlevin, metin çözücüler tarafından da anlamlandırılabilir olması gereği vardır. Metindilbilimde çıkarsamalar ve akıl yürütme, metin içinde açık olarak belirtilen bir bilgiden ya da okurun kültürel ve ansiklopedik olarak bildiği varsayılan bir bilgiden yola çıkarak, söylenmemiş yeni bir bilgiyi çıkarma işidir. Yazar, okuyucusunun sahip olduğunu varsaydığı bilgiler için ayrıntıya girmez. Bu bilgiler gerektiğinde kullanılmak üzere okuyucunun belleğinde bulunan bilgilerdir (Aşkın Balc1, 2006, s. 191-204).

Bizim burada gerçekleştirmek istediğimiz çalışmaya gelince, edebî bir romanda geçen çeşitli nesnelerin yer aldığı sözceler seçilecek, ilgili nesneleri niteleyen dilsel göstergeler (daha ziyade niteleme/niteleyici kiplikler) dilbilimsel bir yaklaşımla incelenecek ve böylece sözcelerin derin yapıları söylem çözümlemesi yöntemiyle yorumlanmaya çalışılacaktır. Özellikle nesnelere bağlı olarak onları niteleyen "Niteleme kiplikleri” işlevindeki sıfatlar belirlenerek sözceleme bağlamındaki anlamsal boyutu irdelenecektir. Yazar tarafından kaleme alınan ve nesneyi kahramanın gözünde anlamlandıran "Niteleme kiplikleri + Nesneler" 
Yılmaz, S. ve Kılı̧̣, M. (2021). Klasik bir edebî romanda nesne adlarında kullanılan göstergelerin yorumlanması. Humanitas, 9(18), 342-365.

şeklindeki dilsel kullanım doğal olarak genellikle öznel bir değer taşır. Bu çalışmanın temel amacı, romanda nesne adları sınıflandırarak dilsel göstergeler aracılığıyla yorumlama sürecinde "nesne - insan" ilişkisi, daha açık bir ifadeyle nesne ile zihni ve bilinç, nesne ile insanın ruhsal durumu arasındaki bağlantının irdelenmesidir. Diğer yandan, nesneleri barındıran sözcelerin anlamsal değerinin yanı sıra yazar tarafından sosyo-kültürel açıdan okurlara dolayısıyla topluma aktarılmak istenen iletinin etkisi de böylece mercek altına alınacaktır. Sözce ve göstergelerinin derinlemesine incelenmesinde, Söylem Dilbilimi alanı kapsamına giren Sözceleme kuramı (fr. énonciation, ing. enunciation) kullanılacaktır. Araştırmanın neticesinde, Emile Zola'nın romanda nesneleri kaleme aldı̆̆ı sözcelerde kurgularken benimsediği biçemsel söylem tarzı da böylece aydınlığa kavuşmuş olacaktır. Alanda yabancı dildeki her terime Türkçe karşılık bulunamadığı bilinen bir gerçektir, bu nedenle bu makalede kavram sorunu nedeniyle daha ziyade Türkiye'de dilbilim ve göstergebilim alanlarında yapılan çalışmalardan yararlanacağız.

\section{Kavram Olarak Nesne Nedir?}

Türk Dil Kurumu'nun (TDK) elektronik Güncel Türkçe Sözlüğü’nde “nesne” sözcügünün anlamı "belli bir ağırlığı ve hacmi, rengi olan her türlü cansız varlık, şey, obje; geçişli fiili bütünleyen yalın ve belirtme durumunda bulunan tümleç; öznenin dışında kalan her konu, obje" olarak verilir (Nesne, 2019). Diğer yandan, elektronik Misalli Büyük Türkçe Sözlüğ̈̈’nde ise "nesne” kavramı, bu anlamlardan farklı olarak "Öznenin, zihin ve bilincin dışında ve ondan ayrı olarak bulunan şey, bilgiye konu olan şey, obje” şeklinde tanımlanmaktadır (Nesne, t.b.). Bu tanımda, nesnenin zihin ve bilinçten soyutlanması, insanın hafızasından kopuk, düşüncesinden bağımsız gösterilmesi dikkat çekicidir. Bu çalışmada, nesne ile insan zihni, bilinci ve düşüncesinin yanı sıra, insanın ruhsal yapısı arasındaki ilişki mercek altına alınacaktır.

\section{Romanda Nesne Olgusu}

$\mathrm{Bu}$ genel bilgilerden sonra, romanda nesne okumaları konusuyla ilgili olarak bir giriş yapmak yerinde olacaktır. Roman kendi özünde bir göstergeler bütünüdür. Orhan Pamuk (2008) "Masumiyet Müzesi” romanı hakkında konuşurken şöyle diyor: "Bir dizi eşyayı içgüdüyle seçtikten sonra önümüze koyup onları bir hikâyeyle birleştirip kahramanların hayatlarına nasıl katabileceğimizi düşlüyorsak, bir roman kurmaya başlamışız demektir.” Maddi nesnelerin edebî yapıdaki kurgulanışını çözümlemek, romanı diğer yazınsal türlerden ayırt eden özellikleri anlayabilmek açısından kilit bir önem taşır. Romanda nesne çoğu zaman “mekân/uzam” başlı̆̆ı altında bir alt birim gibi görülse de birçok eserde okurun karşısına 
Yılmaz, S. ve Kılı̧̣, M. (2021). Klasik bir edebî romanda nesne adlarında kullanılan göstergelerin yorumlanması. Humanitas, 9(18), 342-365.

mekânı bütünleyen bir parça olarak değil, bireyin öncelikle fiziksel, daha sonra da ruhsal anlamda varlığını kuşatan bir alan olarak çıkmaktadır. Anlatı boyunca belli nesnelerin sıkça tekrar edilmesi ve bunlara farklı işlevlerin yüklenmesi nesnenin anlatıda kazandığı boyutu görmek açısından önemlidir.

İlk roman eleştirilerinde kullanılan "yapısalcı yaklaşım” nesnenin sadece gerçeklik algısı için var olduğunu, dolayısıyla gereksiz ve detaylı betimlemenin eserin değerini olumsuz etkileyeceği yönünde değerlendirmeler yapmıştır. Oysaki anlatıda nesnelerin sadece doğrudan yarattığı gerçeklik etkisine değil, karakter ve atmosfer yaratma gibi diğer dolaylı işlevlerine de dikkat çekmek gerekmektedir. Bugüne kadar yapılan roman eleştirilerine baktığımızda, nesnelerin hakiki ve mecazi (değişmeceli) olmak üzere iki temel fonksiyonu olduğu görülür. Nesneler anlatıda başka herhangi bir şeyi anlamlandırmadan saf bir hâlde, kendileri olarak var olduklarında gerçeklik etkisi yaratmakta, metaforik veya metonimik olarak kullanıldıklarında ise karakter ve atmosfer yaratımına katkıda bulunmaktadır.

Anlatıda nesne okumaları ile ilgili çalışmalar 2000'li yıllardan sonra çok farklı boyutlar kazanmıştır (Uçar, 2012, s. 10-44). Bu çalışmaları kısaca sıralayacak olursak:

- Nesne okumalarını metaforik, metonimik ve düz anlam olmak üzere üç grupta toplayan, düz okumalarda nesnenin tarihsel ve kültürel göndermeleri mutlaka değerlendiren çalışmalar.

- Anlatıda nesnelerin değerlerini dörde ayırarak inceleyen çalışmalar: Kullanım değeri (araçsal değer), değişim değeri (ekonomik değer), simgesel değer (bireysel değer) ve göstergesel değer (toplumsal değer).

- "Nesneler göstergelerdir, psişik enerjinin nesnelleştirilmiş biçimleridir" diyen yazarlar ise, nesneleri temel olarak üç bağlamda ele alarak değerlendirdiler: a) Benlik ve yaratım simgesi nesneler (yeni bir elbise giyen kadının bir anda kendini daha güzel ve farklı hissetmesi, kendi arabasını sürdüğü için genç bir adamın özgür hissetmesi gibi), b) Statü simgesi olarak nesneler (sahiplerinin başkalarını kontrol etme güçlerini yansitan nesneler), c) Toplumsal bütünleşme/farklılaşma simgesi olarak nesneler (ortak miras, din, etnik köken veya yaşam tarzı).

Her sanatçı kendi bireysel dünyasını yaratmak için nesneleri kullanır. Nesneler bazen anlatıcı tarafından tutarlı ve düzenli bir biçimde kişileştirilir ve özel güçlerle beslenir, öyle ki bu nesnelere nesne-karakter demek mümkündür. Bazen de tersi bir kurgu gerçekleştirilir. Bir karakter bir nesneye benzetilir ya da bir nesneyle yer değiştirir. Bunu yaparken yazar anlatıma bir biçem katmak için yerine göre ikame (yer değiştirmece), mecaz-i mürsel, 
Yılmaz, S. ve Kılı̧̧, M. (2021). Klasik bir edebî romanda nesne adlarında kullanılan göstergelerin yorumlanması. Humanitas, 9(18), 342-365.

benzetme/karşllaştırma gibi söz sanatlarına başvurabilir. Bir başka nesne yorumlaması ise nesnemsi ya da statü nesneleridir ki bunlar roman karakterlerini bir araya getirerek toplumsallaşmalarına olanak sağlayanlardır. Romanlarda en çok rastlanan nesneler ise metonimik olanlardır. Metonimik nesneler ile kastedilen bir nesne ile başka bir nesne/kavram/kişi arasında olumsal ya da çağrışımsal ilişki kurulmasıdır.

Şunu da belirtmek gerekir ki, bir anlatıda bir nesne sürekli aynı işleviyle kullanılmamaktadır. Yukarıda sözü edilen kategoriler sabit olmayıp anlatının belli bir anında nesnenin büründüğü bir hâle göndermede bulunmak suretiyle de gerçekleşebilir. Dolayısıyla, bu kategoriler nesnenin anlatıda bürünebileceği çeşitli görünümlere işaret etmektedir. Başka bir ifadeyle, bir nesne anlatının bir noktasında karakter-nesne hâlinde kurgulanırken, diğer noktalarında karakteri betimleyen metonimik bir nesne veya mekân işlevi üstlenen bir nesnemsi olarak karşımıza çıkabilir.

\section{Emile Zola'da Nesne Olgusu}

Şimdi Emile Zola'da nesne olgusuna geçebiliriz. Bu araştırmada Zola'nın "Claude'un İtirafları" adlı romanında "nesne" okumalarını yüzeysel değil derinlemesine okuma anlamında değerlendirmeye çalışacağız. Romandaki nesneleri okumaya geçmeden önce, Mutluay'ın (1979) aktardığına göre, Zola "Deneysel Roman" (fr. Le Roman Expérimental) başlıklı yazısında nesne kullanımını tasvirle bağdaştırarak kısaca şöyle bir ifadede bulunur:

Artık zevk olsun diye, tasvir için tasvir etmiyoruz. İnsanın, çevresinden ayrılamayacağını, elbisesi, evi, şehri, ülkesi ile tamamlandığını kabul ediyoruz. Bu bakımdan beyninin ya da yüreğinin tek bir olayını, çevrede onun sebeplerini ya da tepkisini aramadan, tespit etmeyeceğiz. Sonu gelmez tasvirlerimizin sebebi işte budur.

Bir başka başlangıç noktası ise doğrudan doğruya romandan alınan ve Zola'da "nesne" olgusunu en iyi tasvir eden, onun nesneye bakışını bir nevi özetleyen şu sözce olabilir:

(1) 'Oysa bir ay öncesine kadar ne kadar özgürdüm, Laurence'1 sokağa attlmayacak bir eşya gibi sakliyordum. Şimdi o beni kendine bağlad, ona göz kulak oluyor, onu uyurken gözlüyor, beni bırakmasını istemiyorum" (Zola, 2011, s. 79).

Birlikte yaşadığı kadını sokağa atılamayacak bir eşya olarak gören ve eşyaya giderek bağlanan bir roman kahramanı karşımıza çıkıyor. Buna benzer söylemlerden öyle anlaşılıyor ki, roman nesneler üzerine kuruluyor, nesneler insanlaşırken insanlar nesneleşiyor. Bunu "kişileştirme" ve "nesneleştirme" olarak ifade edebiliriz. Böylece, nesneler ile ona nitelik kazandıran çeşitli dilsel göstergelerin kullanımın yanı sıra "insan-nesne" ilişkileri, romanda başta kahraman olmak üzere kişilerin (dolayısıyla da yazarın) ruh hallerini, psikolojik 
Yılmaz, S. ve Kılı̧̣, M. (2021). Klasik bir edebî romanda nesne adlarında kullanılan göstergelerin yorumlanması. Humanitas, 9(18), 342-365.

durumlarını ortaya koyuyor. Naturalizm akımı çerçevesinde, bilimsellik hırsına rağmen Zola'nın yoğun ve çarpıcı betimlemelerle dolu romanları nesneler açısından çok zengin bir göstergeler dizgesi içerir. Gözü ve kalemiyle bütün nesnelerin biçimlerini değiştiren ya da büyüten Zola, okura yaşamın dev bir hayalini sunar. Çılgınca fantezileriyle tüm hareketsiz biçimleri canlandıran, her şeyi önümüzde bazen bir rüya, bazen de bir kâbus gibi dans ettiren, sınır tanımayan sıra dışı bir yazardır.

Zola neredeyse her romanında olduğu gibi, bu eserinde de uzama ve nesneye son derece büyük bir dikkatle bakmış, özellikle anlatıya yerleştirdiği her nesneye mutlaka özel bir ruh kazandırmıştır. Bu çalışmada üzerinde durulan "nesne", salt eşya olan vazo, mobilya gibi günlük hayatın kullanımına açık araç ve gereçler, kısaca sade ev eşyalarıdır. Ayrıca çatı katı, merdiven, sığınak, balo salonu gibi mekân ifade eden söz ve söz grupları da çalışmaya dâhil edilmemiştir. Romanda tekrar sıklığı ile dikkati çeken perde, aydınlatma (mum, şamdan, lamba, avize), mobilya, vazo, yatak, duvar, pencere, hall, kumaş, klymetli madenler, giysi nesneleri olmuştur. Bu nesneler çalışma konusu içine alınırken bir kez geçen nesneler (makas, kalem, kâğıt, şişe, bot, araba, maske, kibrit, şömine, küvet, sürahi, yastık vb.) gösterge anlamında yeterli ipucu vermeyeceği için çalışma konusuna dâhil edilmemiştir. Ayrıca çalışmaya dâhil edilen mum, şamdan, avize, lamba, ateş gibi aydınlatma nesneleri hep belli çağrışım özellikleri ile kullanıldığı için bir başlık altına alınarak incelenecektir.

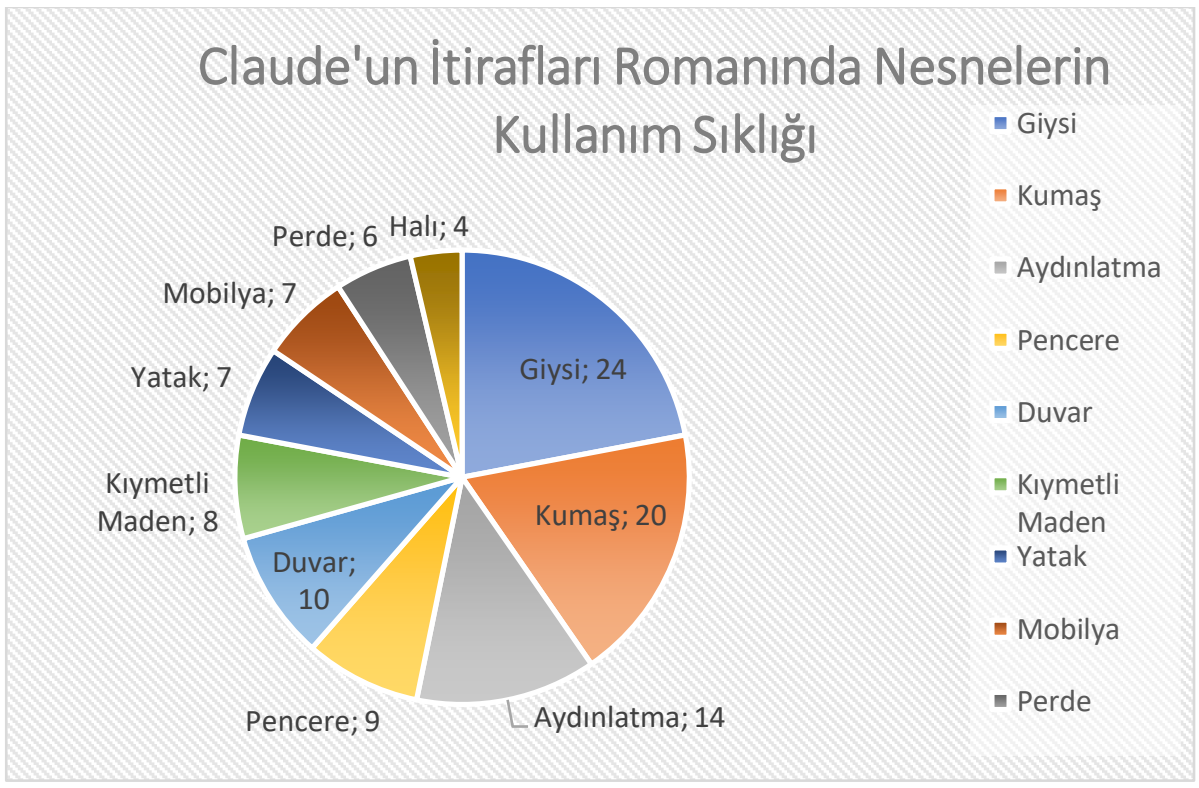

Şekil 5. Nesnelerin kullanım sıklığı istatistiği

$\mathrm{Bu}$ çalışmada nesnelerin geçtiği 112 sözce veri olarak seçilmiş, bu sözceler içinden nesnenin farklı değerler kazandığı ifadeler belirlenerek yorumlanmaya çalışılacaktır. 
Yılmaz, S. ve Kılı̧̣, M. (2021). Klasik bir edebî romanda nesne adlarında kullanılan göstergelerin yorumlanması. Humanitas, 9(18), 342-365.

Nesnelerin yorumlama sırası eserdeki sıralanışları dikkate alınarak oluşturulmuş, ancak aydınlatma nesneleri birkaç nesneyi içerdiğinden en son grup olarak incelenecektir.

\section{Perde Nesnesi}

\section{Perde Örnekçesi}

(2) "Ben büyük perdeleri, uzun şamdanları, makasın büyük bir güçle temas ettiği mermerleri severim.” (Zola, 2011, s. 17).

Nesneye nitelik kazandıran gösterge : Büyük, sevmek.

(3) "Biliyor musunuz, insan yalnızken, çiçeksiz, gözlerini dikeceği beyaz perdesiz bir ortamda ne kadar üşür.” (Zola, 2011, s. 16).

Nesneye nitelik kazandıran gösterge: Perdesiz, yalnız, üşümek

Roman boyunca nesnelerin kullanım değerlerinden çok toplumsal sınıf/konum değerleri üzerinde durulmuştur. Batı kültüründe perde bir zenginlik, bir sosyal sınıf göstergesidir. "Perde" nesnesi varlığı ile bir öz güven duygusu, güç, rahatlık simgesi olurken, yokluğu ile yoksulluk, çaresizlik, kendini değersiz hissetme çağrışımını oluşturmaktadır. Muhtemelen romanın kahramanı da perdesi olan çatı katındaki bir odada kendini daha iyi hissederek güçlü bir benlik algısı oluşturacaktır. Genel kanıya göre ve toplumsal kültürlere bağlı olarak, perde gerçekten bir evi yuva yapan, mekâna ruh katan, yerleşiklik duygusu veren bir nesne özelliği taşıyabilir. Perdeleri temizlemek maksadıyla çıkardığımızda, tıpkı Zola'nın anlattığı gibi üşüdüğümüzü, güneşin 1şı̆̆ının bile odayı şenlendiremediğini hissedebiliriz. Perde nesnesi çoğunlukla pencere için "perdesiz" ya da "yüksek, uzun, ince muslin perde, beyaz perde" gibi niteleyici kipliklerle birlikte daha çok öznel ya da değerlendirici ifadeler içinde yer almıştır. Burada perde nesnesinin yanında onu niteleyen çeşitli sıfatların yoğun kullanımı dikkat çekicidir.

\section{Mobilya Nesnesi}

Mobilya Örnekçesi

(4) "Ve adam neşelenmek için sadece hoş beyaz tuvallerle, basit ama alımlı mobilyalar isteyince, onu daha fazla hoşnut edemediğim için üzülüyorum.” (Zola, 2011, s. $14)$.

Nesneye nitelik kazandıran göstergeler: basit ama alımlı, neşelendiren, hoşnut eden.

(5) Akşam 17 numaraya indim. Oda yapmacık bir gösterişle möbleli ve Paris’in şatafatlı otelleri gibi dayalı döşeliydi. Bu kırmızı kumaşların, tozdan eskimiş ve grileşmiş bu koyu ve yă̆lı mobilyalar, bu çatlak çiniler, bu değersiz eşyalar, nemli duvarlar boyunca uzanan 
Yılmaz, S. ve Kılı̧̧, M. (2021). Klasik bir edebî romanda nesne adlarında kullanılan göstergelerin yorumlanması. Humanitas, 9(18), 342-365.

paçavralar ve kırıntı döküntüler, bütün bunların nasıl da bayağl ve utanç verici bir görüntü sergilediklerini tahmin edemezsiniz kardeşlerim. Çatı katındaki odam, her zamankinden daha çıplak, fakat daha çirkin değildir. Yüksek ve geniş ince muslin perdeleriyle süslenmiş iki pencere bütün bu yıkıntıların üzerine çok kuvvetli bir 1şık veriyordu. Oracıkta rengi solmuş tüllerle çevrili bir yatak vardı. Donuk camı olan ve yan kapıları bozuk bir dolap, ĭgrenç, eski püskü, çok kullanılmaktan sararmış kanepe ve koltuklar, sonra bir tuvalet bir çalışma masası, diğer bir masa, sandalyeler, takımı bozulmuş mobilyalar, yemek salonu mobilyaları, yatak odası, salon, küçük oda mobilyaları da vardı. Bu takımın anlayamadığım bir kendini beğenmişliği ve pisliği seziliyordu. İlk bakışta doğru dürüst bir odaya girdiğinizi sanırdınız; sonra maun ağac1 ve damasko üzerindeki kir görünür, bir çeşit kötülük ve pislik hissine kapılırsiniz. (Zola, 2011, s. 57).

Nesneye nitelik kazandıran göstergeler: Yapmacık bir gösterişli, tozdan grileşmiş, koyu, yağlı, bayağı, utanç verici, bozuk, iğrenç, eski püskü, çok kullanılmaktan sararmış, takımı bozulmuş, kendini beğenmiş, pis, değersiz, bir çeşit kötülük ve pislik hissine kapılmanıza neden olan.

Romanda sürekli işlenen bir başka nesne ise mobilyalardır. Roman kahramanı bir sözcesinde "neşelenmek" için basit ama alımlı mobilyalar ister. Kapalı mekân tasvirlerinde mobilyalar bütün detayları ile anlatılırken, renkleri, şekilleri, yeni ya da eski, temiz ya da kirli oluşları onlara farklı bir kişilik kazandırır. Çoğu zaman odasında mobilyaların yokluğundan şikâyet eden roman kahramanı, bazen de mobilyaların insana verdiği kötülük ve pislik hissinden bahseder ve çatı katındaki odası hakkında "her zamankinden daha çıplak, fakat daha çirkin değildir" diyerek arzuladığı mobilyaların niteliğini de ortaya koyar. Fakat mobilya sahibi insanları da kıskanmadan edemez. Bir başka yerde ise mobilyalar bir gösteriş unsurudur. Bütün bu söylemlerden varılan netice, mobilya da tıpkı perde gibi bir sosyal statü göstergesi olmaktan başka kişilerin kendine güven duyması ve mutlu huzurlu bir ortam oluşturabilmesi için mutlaka gereklidir. Mobilyalara bir ruh kazandıran yazar, onları bazen kendini beğenmiş, bazen kötü diyerek mekânın tasvirinde ön plana çıkarır.

Bu başlık altında incelediğimiz sözcelerde kullanılan sıfatlar değerlendirildiğinde daha çok öznel ya da değerlendirici sıfatlar dikkat çekmektedir. Ayrıca bu grupta nesne betimlemeleri için oluşturulan sözceler çalışma için belirlenen sözce tablosundaki en uzun sözce gruplarıdır (40-42 kelime). 
Yılmaz, S. ve Kılı̧̣, M. (2021). Klasik bir edebî romanda nesne adlarında kullanılan göstergelerin yorumlanması. Humanitas, 9(18), 342-365.

\section{Vazo Nesnesi}

Vazo Örnekçesi

(6) "Solgun çiçekli çini vazoların bulunduğu evin önünde duraklıyorum. Ve her şeyin yalnızlıkla yoksulluktan şikâyet ettiğini duyar gibi oluyorum.” (Zola, 2011, s. 13).

Nesneye nitelik kazandıran göstergeler: Solgun çiçek, çini, yalnızlık ve yoksulluktan şikâyet.

(7) "Ev neşe saçan büyük bir ateş istiyor, kar yağışını unutan vazolar taze gül istiyor.” (Zola, 2011, s. 14).

Nesneye nitelik kazandıran göstergeler: Taze gül, büyük ateş, neşe saçmak.

Roman boyunca iki sözcede geçen "vazo" nesnesi ise içindeki çiçeklerle ruh kazanırlar. Bazen solgun çiçekler yoksulluktan şikâyet eder, bazen de mevsim ne olursa olsun taze gül isterler, çünkü taze gül hayatın canlılığı, evin neşesidir. Vazoların kişileştirildiği bu iki sözcede yine değerlendirici niteleme kiplikleri dikkat çekmektedir.

\section{Yatak Nesnesi}

Yatak Örnekçesi

(8) “İlk öpücük sırasında sevgilinin, dantel ve takılarla süslü olması gereklidir, altın ve mermerden dört perinin taşılı̆̆l yatağın üstü değerli taşlarla dolu, çarşafları saten kumaştan olsun.” (Zola, 2011, s. 24).

Nesneye nitelik kazandıran göstergeler: Altın ve mermerden dört perinin taşıdı̆̆ değerli taşlarla dolu, çarşafları saten, içinde dantel ve takılarla süslü bir kadın olan.

(9) “Aş̧ rüyalarımızda bir çatı katının karanlı̆̆ında, bir akşam, bir kötü yatak bulabileceğimizi ve bu kötü yatakta pislik bir klzın yarı çıplak uyuyacağını hiç düşünmemiştik." (Zola, 2011, s. 25).

Nesneye nitelik kazandıran göstergeler: Kötü, çatı katının yarı karanlığında, içinde pislik bir k1z olan.

Yukarıdaki örnekler incelendiğinde, "yatak" nesne olarak karakterin duygularına ve düşlerini uzamsal olarak kaplayan bir yer olarak kurgulanmıştır. Yaşadığı mekânlarda hep pis, eski, kırışık çarşafları olan yataklar varken, yazarın hayallerinde ise tertemiz, saten çarşaflı, kıymetli taşlarla süslü yataklar vardır. Yatakların pis ve eski olmasıyla kadın-erkek ilişkileri bağdaştırılmıştır. Böyle bir yatakta kurulan ilişkinin de temiz ve masum olması beklenemez. Yatak nesnesi tezatlar üzerinden işlenerek niteleyici kipliklerle okuyucunun zihninde görselleştirilmiş, bu görselleştirmede değerlendirici sıfatlar ön plana çıkmıştır. 
Yılmaz, S. ve Kılı̧̧, M. (2021). Klasik bir edebî romanda nesne adlarında kullanılan göstergelerin yorumlanması. Humanitas, 9(18), 342-365.

\section{Duvar Nesnesi}

Duvar Örnekçesi

(10) “(...) perdeden yoksun pencere, sonsuzluğa dek dimdik, sert ve kapkara bir duvara açı1ıyor.” (Zola, 2011, s. 13).

Nesneye nitelik kazandıran göstergeler: Dimdik, sert, kapkara.

(11) “Güneş doğarken olduğu gibi, bu solgun ve açık gökyüzünde gençliğim canlanıverdi. Büyük duvara baktım, açık seçik ve temizdi, taşların arasında otlar filizlenmişti." (Zola, 2011, s. 89).

Nesneye nitelik kazandıran göstergeler: Açık seçik, temiz, taşları arasında otlar filizlenen.

Yukarıdaki örnekleri incelediğimizde, "duvar" nesnesi diğer birçok anlatıda olduğu gibi ruh kazandırılan nesnelerden biridir. Genel olarak duvar yol kesen, özgürlügü sınırlayan bir nesne olarak yer alırken Zola'da odanın iç duvarlarının çıplaklığı, kocaman çatlakları ile adeta bir yoksulluk simgesi olmuştur. Pencerenin manzarasını kesen duvar ise kahramanın ruh haline göre farklı tasvir edilir: Bazen sert ve kapkara, bazen açık seçik ve tertemizdir. Birçok romanda işlenen duvar nesnesi Zola'nın eserinde de tezatlar üzerinden canlı bir varlık betimi yaparcasına sözcelerle anlatıya girmiş, niteleyici kipliklerle desteklenerek bazen olumlu bazen olumsuz duyguları harekete geçirecek şekilde betimlenmiştir.

\section{Pencere Nesnesi}

\section{Pencere Örnekçesi}

(12) "Ah! Seslerimizin çatı penceresi ne kadar da beyazdı! Pencere güneşle nasıl şenleniyordu, yoksulluk ve yalnızlık hayatı nasıl da ciddi ve çekilmez hale getiriyordu." (Zola, 2011, s. 15).

Nesneye nitelik kazandıran göstergeler: Beyaz, güneşle şenlenen, şen.

(13) "Bizim için sefalet güneşin ve gülümsemenin gösterişine sahipti. Ama biliyor musunuz ki, gerçek bir çatı penceresi ne kadar da çirkindir?” (Zola, 2011, s. 16).

Nesneye nitelik kazandıran göstergeler: Sefalet, gerçek, çirkin.

(14) "Hayır bu pencere güneşi benden esirgiyor, bu döşeme nemli, bu çatı katı sessiz sakin. Sevemiyorum, burada çalışamıyorum.” (Zola, 2011, s. 16).

Nesneye nitelik kazandıran göstergeler: Güneşi esirgeyen 
Yılmaz, S. ve Kılı̧̧, M. (2021). Klasik bir edebî romanda nesne adlarında kullanılan göstergelerin yorumlanması. Humanitas, 9(18), 342-365.

(15) "Sabahları puslu, soğuk ve kapalıdır; gün, kapalı ve hüzünlü olarak perdesiz pencereden giriyor; pencere camlarl ile duvarların üzerinde üzüntü ile geziniyor.” (Zola, 2011, s. 66).

Nesneye nitelik kazandıran göstergeler: Hüzünlü, perdesiz, ışığın camları üzerinde üzüntü ile gezdiği.

Yukarıdaki sözcelerdeki anlatıda eşyanın görünümlerinin kahramanın ruh hâllerine göre değişebildiğini görüyoruz. Pencere nesnesi ve onun içeriye bıraktığı gün 1şığ1 ya da pencereden görünen manzara sanki doğrudan kahramanın hissettiklerini yansıtır. Bazen gün 1şığı ve güneşle şenlenen pencere, bazen gün ışığını kahramanımızdan esirger, içeri girse bile duvarlardaki yansıması hüzünlüdür. Zola'nın nesne betimlemelerindeki iki temel unsur tezat ve değerlendirici niteleme kiplikleri burada da dikkat çekmektedir.

\section{Halı Nesnesi}

Halı Örnekçesi

(16) "Dinliyorum, ancak üzüntü duyabiliyorum. Tavana asabileceğim avizelerim ve döşeme taşlarını saklamak için halılarım yok.” (Zola, 2011, s. 14).

Nesneye nitelik kazandıran göstergeler: Döşeme taşlarını saklamak için halı, üzüntü, yok.

(17) "Soylu konaklara ihtiyacım var. Ya da daha ziyade, yumuşak, serin ve kokulu halılarıyla, yaprak örtüleriyle, geniş 1şıltılı ufukları olan alanlara ihtiyacım var."

(Zola, 2011, s. 17).

Nesneye nitelik kazandıran göstergeler: Soylu, yumuşak, serin, kokulu.

Yukarıdaki sözcelerin bağlamını incelediğimizde, yine uzam olarak söz konusu mekânın (çatı katı, salon) dekorasyonu ile doğrudan bağlantı kurulan "halılar" soyluluk, zenginlik, refah ve huzur veren eşyalardır. Oysa kahramanımızın yumuşak, kokulu halıları yoktur; döşemeler ise soğuktur ve roman kahramanını çalışamaz hale getirir. Halının varlığı ve yokluğu arasındaki hissiyat aracılığı ile oluşturulan tezat yine halıyı değerlendiren niteleme kiplikleri dikkat çekmektedir.

\section{Kumaş Nesnesi}

Kumaş Örnekçesi

(18) “Renkleri solmuş damasko parçaları yatağın üstünden sarkıyor...” (Zola, 2011, s. 13).

Nesneye Nitelik Kazandıran Göstergeler: Renkleri solmuş. 
Yılmaz, S. ve Kılı̧̣, M. (2021). Klasik bir edebî romanda nesne adlarında kullanılan göstergelerin yorumlanması. Humanitas, 9(18), 342-365.

(19) "Bağışlayın beni kardeşlerim, ipek o kadar yumuşak, dantel o denli hafif ki..." (Zola, 2011, s. 17).

Nesneye Nitelik Kazandıran Göstergeler: Yumuşak, hafif.

(20) "Ve şimdi dostlar kalabalık içinde örtünmek için değil ama zengin ve harika kumaşın altında daha geniş bir yaşam için lal rengindeki bir kumaşı omuzlarıma çekmekten hoşlanabilirim.” (Zola, 2011, s. 19).

Nesneye Nitelik Kazandıran Göstergeler: Kalabalık içinde örtünmek için değil, zengin, harika, geniş, hoşlanmak.

(21) "Kendime yol açmak için, ayağımla paçavraları itekleyerek ilerliyordum ki, tümüyle mavi ipek ve kadife düğmelerle süslenmiş yepyeni ve güzel bir kadın elbisesi fark ettim." (Zola, 2011, s. 24).

Nesneye Nitelik Kazandıran Göstergeler: Süslü, güzel, yepyeni.

Yukarıdaki örnekleri incelediğimizde, kumaş nesnesinin kullanım değerinden çok değişim ve süs değeri ön plana çıkar. Nesnenin sadece dış görünümünü değil, sahibinin sınıfsal konumunu ve karakter özelliklerini de betimlemeye hizmet eder. İpek, saten, kadife, dantel, muslin kahraman için refah işaretleridir. Nesne olarak kumaşı ve onun yazar için anlamını en güzel şu sözce ortaya koymaktadır:

(22) "Ve şimdi dostlar kalabalık içinde örtünmek için değil ama zengin ve harika kumaşın altında daha geniş bir yaşam için lal rengindeki bir kumaşı omuzlarıma çekmekten hoşlanabilirim.” (Zola, 2011, s. 19).

Nesneye Nitelik Kazandıran Göstergeler: zengin ve harika, lal rengindeki

Burada artık kumaş bir toplumsal değer niteliğindedir; bireyin toplum içindeki statüsünün göstergesidir. Değerlendirici sıfatlar yanında statü göstergesi olan niteleyici kiplikler olarak şunlar dikkat çeker: "Zengin, geniş, yepyeni, sadece örtünmek için olmayan."

\section{Kıymetli Madenler Nesnesi}

Klymetli Madenler Örnekçesi

(23) “Kokulu çeşmelerde mermer banyolar, gümüş kafeslerdeki hanımeli bitkiler, tavanları yaldızlarla dolu uçsuz bucaksız salonlar, meleklerin yirmi yaşındaki bir erkek için yapmaları gereken saray bu değil midir?” (Zola, 2011, s. 19).

Nesneye Nitelik Kazandıran Göstergeler: Kokulu, hanımeli, meleklerin yirmi yaşındaki bir erkek için yapmaları gereken saray. 
Yılmaz, S. ve Kılı̧̧, M. (2021). Klasik bir edebî romanda nesne adlarında kullanılan göstergelerin yorumlanması. Humanitas, 9(18), 342-365.

(24) "Zemin katta, altın ve ipek bir yuvada yaşıyordum. Her beş y1lda bir üst kata çıktım. Bugün çatı katında oturuyorum. Mezara gitmek için aşağı inmem gerekiyor. Ah! Arkadaşınız Laurence ne kadar mutlu ki daha henüz üçüncü katta oturuyor.” (Zola, 2011, s. $31)$.

Nesneye Nitelik Kazandıran Göstergeler: Yuva, mutlu.

Yukarıdaki sözcelerin bağlamsal anlamına indiğimizde, yine sosyal konum göstergeleri içinde yer alan mermer nesnesi, altın, kristal, gümüş, elmas, bronz, değerli taşlar kahramanın hayallerini süsler. Değerli madenleri niteleyen niteleyici kiplikler genelde olumludur ve sözcelerin verdiği iletiye bakılırsa bu madenlerin varlığı roman kahramanını mutlu etmektedir.

\section{Giysi/Elbise Nesnesi}

\section{Giysi/Elbise Örnekçesi}

(25) "Kendime yol açmak için, ayağımla paçavraları itekleyerek ilerliyordum ki, tümüyle mavi ipek ve kadife düğmelerle süslenmiş yepyeni ve güzel bir kadın elbisesi fark ettim.” (Zola, 2011, s. 24).

Nesneye Nitelik Kazandıran Göstergeler: Süslü, yepyeni, güzel.

(26) Laurence ya kendini yatağa atıyor ya da ağır adımlarla geziniyor. Sanki ăglayan ipek mavi elbisesi, mobilyalar arasında kırışarak sürünüyor. Bu paçavra yağdan sapsarı olmuş, yırtık pırtık, dikişleri atmış, ütülü yerleri bozulmuş görünüyor. Laurence bu elbiseyi hiç temizleyip onarmadan çürümeye parçalanmaya bırakıyor. Sabahtan bir tek elbisesi bu olduğu için bunu giyiyor ve düğümü çözülmüş saçları, üzerinde sırtını ve boğazını gösteren oldukça açık bir balo elbisesi, bu halde sefil odada gün boyunca dolanıyor. Ve bu elbise, hala yer yer parlayan bu solgun mavi yumuşak ipek rezil çarpık solmuş kötü bir paçavradır. Değerli bir kumaşın yırtık parçalarını sefalet içindeki bu zenginliği soğuktan kızaran bu çıplak omuzları görmek anlayamadığım bir kaygıya neden oluyor (Zola, 2011, s. 67).

Nesneye Nitelik Kazandıran Göstergeler: Ağlayan, paçavra, yağdan sapsarı olmuş, yırtık pırtık, dikişleri atmış, ütülü yerleri bozulmuş, solgun, rezil, çarpık, kötü, kaygıya neden olan.

(27) Bu sabah birkaç eski giysi sattım. Laurence için bir elbise kiralamaya gittim, aynı akşam baloya gideceğimizi kendisine bildirdim. Boynuma atıldı elbiseyi aldı ve beni unuttu. Her şeridini ve işleme pulunu inceledi. Süslenmekte sabırsız, kumaş hışırtılarında kendinden geçerek, saten bölümlerini omuzlarına attı. Bazen bir gülümsemeyle teşekkür ederek bana dönüyordu. Daha önce beni bu kadar sevmediğini anladım ve tüm iyiliğime rağmen, 
Yılmaz, S. ve Kılı̧̧, M. (2021). Klasik bir edebî romanda nesne adlarında kullanılan göstergelerin yorumlanması. Humanitas, 9(18), 342-365.

saygımdan yapamadığım şeyi, yani kumaş parçalarını neredeyse elinden söküp alacaktım (Zola, 2011, s. 34).

Nesneye Nitelik Kazandıran Göstergeler: Kumaş hışırtıları arasında kendinden geçerek, gülümsemeyle teşekkür ederek, tüm iyiliğime rağmen saygımdan yapamadığım, elinden söküp almak.

(28) (...) iki sevgili birlikte bir öpücükle Tanrının adaletine girdiklerinde, hangi mutlulukla kendilerini aynı aydınlıklara, aynı sonsuzluğa feda ederler! Sadece bakireliklerini birbirlerine verdiler: karşılıklı beyaz sabahlıklarını aldılar ve şimdi her ikisinin üzerinde hala meleklerin klyafeti var (Zola, 2011, s. 29).

Nesneye Nitelik Kazandıran Göstergeler: Tanrının adaleti, mutluluk, aydınlık, meleklerin kıyafeti.

(29) "Bir ağacın dibinde oturup gözlerimle otların içindeki beyaz tenini, şapkasının omuzuna düşmüş halini süzüyordum; bu temiz güzel elbisesinden zevk alıyordum, namusluca giydiği ve kendisine clvıl cıvll bir yatılı ögrenci havası veren bu elbiseyle hafif görünüyordu.” (Zola, 2011, s. 94).

Nesneye Nitelik Kazandıran Göstergeler: Temiz, güzel, zevk almak, namusluca, cıvıl cıvıl, yatılı öğrenci havası veren.

(30) "Enfer Sokağı ile Orleans yoluna girdik. Bütün pencereler mobilyaları gösterircesine açıktı. Kapıların eşiğinde sigara içerek sohbet eden beyaz gömlekli adamlar vard1." (Zola, 2011, s. 90).

Nesneye Nitelik Kazandıran Göstergeler: Pencereleri mobilyaları gösterircesine açık (evlerin kapı eşiğinde), sigara içerek sohbet eden, beyaz.

(31) “Ağaçlıklar sessiz ve ıssız görünüyorlardı, mavi gömlekli adamlar, köylüler, oraya buraya gidiyorlardı; koca bir köpek ağaçların ortasında ciddi bir edayla oturuyordu." (Zola, 2011, s. 90).

Nesneye Nitelik Kazandıran Göstergeler: Oraya buraya giden, köylüler, mavi.

(32) O sırada, Laurence güçlükle ayağa kalktı ve bana bakarak kapıya yöneldi. Kapı eşiğinde bir süre dikildi. Bana büyümüş gibi geldi ve ben, bu son saatte, mavi ipek elbisesinden parçalar taşıdığını gördüğümde, kollarına atılmamak için kendimi zor tuttum. Bu elbiseyi beğeniyordum, gençliğimin bir anısı olarak saklamak için, ondan bir parça yırtmak istedim (Zola, 2011, s. 154).

Nesneye Nitelik Kazandıran Göstergeler: Beğenmek, anı, saklamak. 
Yılmaz, S. ve Kılı̧̧, M. (2021). Klasik bir edebî romanda nesne adlarında kullanılan göstergelerin yorumlanması. Humanitas, 9(18), 342-365.

Yukarıda sıralanan sözcelerin bağlamsal anlamını inceleyelim. "Giysi” nesnesi sadece sınıfsal farklılıkların ve toplumsal statüdeki değişimin değil, karakterin kimliğinin de gösterenidir. Anlatı boyunca Laurence'ın kişiliği hakkında çok fazla bir şey söylenmezken hatta konuşmalarına çok fazla yer verilmezken, elbiseleri üzerindeki detaylı anlatımlar dikkati çekmektedir. Öyle ki, bir karakter olarak ortaya konulan Laurence değil "mavi saten elbise"dir. Romanda beş (5) ayrı yerde anlatı boyunca giderek bir fetiş haline gelen Laurence'ın omuzlarını açıkta bırakan mavi elbise bir dişilik unsuru olarak ön plana çıkar. Ancak diğer taraftan bir kirlenmişliğin de sembolüdür. İlk defa kahraman, Laurence'ın tek giysisi olan o mavi elbiseyi yerlerde paçavralar arasından alarak duvara asar. Ama tek elbise gün geçtikçe eskir, bakımsızlıktan parçalanır, üzerinde kalan parlak kısımlarıyla artık kahramanın içinde inanılmaz kaygılar doğurmaktadır.

Balo için kiralanan pembe elbise ise başka bir duygunun sembolüdür: Elbiseyi alan Laurence o kadar mutludur ki, yaşadığ 1 hayatın tüm sefaletini unutmuştur. İpek elbisenin hışırtıları içinde ikinci planda kaldığını, ezildiğini hisseden kahraman, burada da bir giysiyi ve ona duyulan sevgiyi kıskanır, hatta aklından onu deliler gibi parçalamayı dahi geçirir. Giyim kuşamdaki incelikleri o kadar iyi gözlemler, eşyanın insana kattıklarını gözden kaçırmamak için öylesine çaba gösterir ki Zola, ona göre her giysi mutlaka bir mesaj vermelidir: Laurence, Marie'den aldığı ödünç elbiselerle namuslu bir yatılı okul öğrencisi olur. Bakireliklerini tanrının adaleti içinde birbirine veren eşler, meleklerin kıyafeti olarak değerlendirilen beyaz sabahlıklar içindedir. Eyfel Sokağında beyaz gömlekli adamlar geniş pencereler ve büyük bahçe kapıları önünde sohbet ederken mavi gömlekli adamlar lokantada hizmet ederler.

Bugünün iş dünyasındaki "beyaz yakalılar" memur yönetici pozisyonu, "mavi yakalılar" ise bedensel güçle günlük ücret karşılığı çalışanlar ifadesi ile bağdaşan bir manzaradır. Bütün bunlar şunu göstermektedir: Giysi türlü ruh hallerine giren bir karakter nesnedir, elbiseler yeni bir hayat ve benlik ideali anlamı taşımaktadır.

\section{Aydınlatma Nesnesi}

\section{Aydınlatma Örnekçesi}

(33) "Dün evimde büyük bir ateş vardı. İki muma sahiptim ve yarınları düşünmeden ikisini de yakmıştım. Bir gece çalışmasına hazırlanırken, birden şarkı mırıldandığımın farkına vardım. Çatı katı sıcak ve aydınlık olarak hoş görünüyordu.” (Zola, 2011, s. 22).

Nesneye Nitelik Kazandıran Göstergeler: Büyük, sıcak, aydınlık, şarkı mırıldanmak. 
Yılmaz, S. ve Kılı̧̧, M. (2021). Klasik bir edebî romanda nesne adlarında kullanılan göstergelerin yorumlanması. Humanitas, 9(18), 342-365.

(34) "Bu sabah, eve döndüğümde, mumların tamamını yanarak tükenmiş buldum, evim uzun zamandır ölü gibi cansızdı. Oda soğuk ve karanlıktı ne ateşim ne de ışığım vardı.” (Zola, 2011, s. 27).

Nesneye Nitelik Kazandıran Göstergeler: Tükenmiş, ölü, cansız, soğuk ve karanlık.

(35) "Dinliyorum, ancak üzüntü duyabiliyorum. Tavana asabileceğim avizelerim ve döşeme taşlarını saklamak için halılarım yok.” (Zola, 2011, s. 14).

Nesneye Nitelik Kazandıran Göstergeler: Üzüntü duymak, saklamak, yok.

Romanda mum, şamdan, lamba, avize gibi aydınlatmaya yarayan nesnelerin kullanıldığını görüyoruz. Anlatıda “1şık” eşyanın "ruhu”nu uyandıran ve canlandıran bir ögedir. Mum, şamdan, lamba rüzgârın da etkisiyle titreyen, bunaltan, aydınlığı ve isısıyla neşelendiren, tükendiğinde evi ölü gibi cansız yapan, yani nerdeyse karakterleşen nesne görünümündedirler. Bu canlı nesne roman boyunca sürekli duygu değişimlerinin belirleyicisi olmuştur: Aydınlık, sicak ortamlar kahramanı rahatlatan, huzur veren ortamlarken, diğer yandan soğuk, yarı aydınlık ortamlar kahramanı karamsarlığa iten, sıkıntı veren ortamlar olmuştur. Yine ışık ile ilgili olarak, bu aydınlatma kaynağının bir sosyal sınıf göstergesi olması da söz konusudur: Mum, lamba yoksulluk işareti iken, şamdan, avize zenginlik, ihtişam ve güç işareti olarak işlenmektedir.

Işığıı varlığı "büyük, sıcak, aydınlık" gibi olumlu niteleyici kipliklerle anlatılırken, hatta ateş ve ışı̆̆ın varlığında kahraman farkına varmadan şarkı mırıldanmaya başladığında yokluğu “cansız, soğuk, karanlık, ölü, tükenmiş” gibi olumsuz anlam içeren niteleyici kipliklerle anlatılmıştır.

\section{Sonuç}

Claude'un İtiraflarl adlı romanda nesnelerin yeri ve önemi üzerine yapılan incelemede, nesnelerin sadece doğrudan yarattı̆̆ gerçeklik etkisiyle değil, diğer dolaylı işlevlerine de dikkat çekilerek kullanıldığı tespit edilmiştir. Bu dolaylı işlev çoğunlukla karakter (mavi saten elbise) ve atmosfer yaratma (pencere, duvar, mum, lamba, ateş, avize, mobilya) şeklindedir. Bir başka açıdan nesneler kullanım ve değişim değerlerinden daha çok simgesel ve göstergesel (kumaşlar, kıymeti madenler) değerleriyle işlenmişlerdir. Özellikle ev aksesuarları ve giysi detayları verilirken, nesnelere benlik ve yaratım simgesi özelliği kazandırılmış, belirli eşyalara ve giysilere sahip roman karakterlerinin belli kişilik özelliklerine de sahip olacağı imgesi çizilmiştir. Sahiplerinin başkalarını kontrol etme güçlerini yansıtan nesneler de sosyal sınıf simgesi (perde, giysi, kumaş, değerli madenler) olarak eserde sıkça rastlanan nesnelerdir. Toplumsal bütünleşmeye ait nesneler ise yine sosyal 
Yılmaz, S. ve Kılı̧̧, M. (2021). Klasik bir edebî romanda nesne adlarında kullanılan göstergelerin yorumlanması. Humanitas, 9(18), 342-365.

sınıfa ilişkin olarak daha çok yaşam tarzı ile ilgili olanlardır. Örneğin, somut olarak balo ile ilgili tüm tamamlayıcı ve dekoratif özellikli nesneler bir yaşam tarzını anlatır.

Nesneler bazen anlatıcı tarafından tutarlı ve düzenli bir biçimde kişileştirilir ve özel güçlerle beslenir, öyle ki bu nesnelere "nesne-karakter" demek mümkündür. Burada, "kişileştirme" söz sanatından behsedebiliriz. Bazen de tersi bir kurgu gerçekleştirilir. Bir karakter bir nesneye benzetilir ya da bir nesneyle yer değiştirilir. Burada da "nesneleştirme" söz konusudur. Örneğin, "mavi saten elbise" kullanımı, bir nesne-karakter kılığında kahramanın gözünde artık bir fetiş haline gelmiş, kılıktan kılığa girerek anlatı boyunca okurun her sahne kurgusunda yer almayı başarmıştır. Aynı nesne üzerindeki tezat teşkil eden ifadeler, özellikle nesneleri niteleyen sözcükler, olumlu çağrışımlar yapan sözcelerle olumsuzluk ifadesi oluşturan sözcelerin neredeyse peş peşe kullanılması okurun kafasında kurduğu uzama ve uzamı kuşatan eşyaya dikkatini artırmış, eşyanın gerçeklik algısı dışında insan psikolojisi ve toplumsal yaşamla ilgili algısını daha belirgin hale getirmiştir.

Eserde yüzey yapıdaki somut bağlaşıklık verilerinden hareketle soyut olan derin yapıya inildiği kolayca görülür. Gösterge bağlamında nesnelerin özel bir değer kazandığ1 sözcelerde "nesne olgusu" adeta bir canlı varlık gibi bulunduğu ortama ve kahramanın duygu durumuna göre değer kazanmaktadır. Güzelim "mavi saten elbise"yi bir paçavra yapan kahramanın içindeki kadının manevi olarak kirlenmiş halidir. Mum bazen soğuktur üşütür, kimi zaman da canlandırır, neşelendirir. Bir başka dikkat çeken nokta, bütün nesnelerin kahramanın etrafinda dönmesi ve onunla anlam kazanmasıdır. Nesneler ile kahraman neredeyse iç içedir, adeta bütünleşmişlerdir; burada "nesne-insan" ilişkisi bakımından bütünleşik bir yapıdan ve onun dilsel kullanımından söz edebiliriz. Hiçbir nesneye başka birinin gözünden bakılamaz. Dolayısıyla nesnelerin gösterge bağlamında kazandığı çağrışımlar da özneldir.

Eserde anlatıcının tutum ve değerlendirmelerini ortaya koyan tüm kiplikler özellikle sıfatların kullanımı yoğun bir biçimde anlatıyı desteklemektedir. Niteleyici ya da niteleme kiplikleri diye tabir edilen dilsel göstergeler daha çok kişiye özgü öznel değerlendirmeler içerir. Yükleniciden bağımsız olarak toplum genelinde daha genelleştirici ve kapsayıcı özellikte olan nesnel diye değerlendirebileceğimiz niteleme kiplikleri bile bağlam içinde kısmen de olsa öznel anlamları yüklenmektedir. Buradan nesnelerin kullanımının yanı sıra nitelendirilmesinde "dilde öznellik" (subjectivity in language) olgusu ve işlevinin ne kadar önemli olduğu sonucuna varılabilir. Tüm bu değerlendirmeler ışığında, üzerinde çalışılan romandaki "nesne kullanımı ve nitelendirilmesi" açısından Zola'nın kendine özgü yoğun ve 
Yılmaz, S. ve Kılı̧̣, M. (2021). Klasik bir edebî romanda nesne adlarında kullanılan göstergelerin yorumlanması. Humanitas, 9(18), 342-365.

etkileyici bir biçemsel söylem geliştirdiğini söylemek mümkündür. Bu özel söylem tarzı da anlamın etkisi olgusuna binaen topluma aktarılmak istenen sosyo-kültürel iletinin etkinliğini beraberinde getirmektedir.

Tablo 1

Nesnelerle Birlikte Kullanılan Sifat ve Kiplikler

Nesneler İçin Kullanılan Sıfat Kiplikler

\begin{tabular}{|c|c|c|c|c|c|c|c|}
\hline \multicolumn{4}{|c|}{$\underline{\text { Nesnel }}$} & \multicolumn{4}{|c|}{$\underline{\text { Öznel }}$} \\
\hline \multicolumn{2}{|c|}{ Renkler } & \multicolumn{2}{|c|}{ Niteleyiciler } & \multicolumn{2}{|l|}{ Duygusal } & \multicolumn{2}{|c|}{ Değerlendirici } \\
\hline Beyaz & 25 & Yoksulluk & 6 & $\begin{array}{l}\text { Neşe, neşeli, neşelendiren, } \\
\text { şen }\end{array}$ & 13 & Yirt1k & 8 \\
\hline Mavi & 18 & Solgun & 5 & Sessiz & 5 & Temiz & 7 \\
\hline $\begin{array}{l}\text { Kırmız1, } \\
\text { lal rengi }\end{array}$ & 10 & Soylu & 2 & Hüzünlü & 3 & Yumuşak & 5 \\
\hline Sar1 & 5 & Namuslu & 2 & Üzüntü & 2 & Gösteriş & 5 \\
\hline $\begin{array}{l}\text { Siyah, } \\
\text { kapkara }\end{array}$ & 4 & & & & & Hafif & 4 \\
\hline Gri & 3 & & & & & $\begin{array}{l}\text { Kirli } \\
\text { Işıkl1, 1ş1ttılı }\end{array}$ & 4 \\
\hline
\end{tabular}

Nesneyi betimleyen sıfat kiplikler dişında, sınırlı sayıda fiil kiplikler (sevmek, üşümek, hoşlanmak, beğenmek, saklamak, zevk almak, üzüntü duymak; isim cümlelerinde var, yok, değil) tespit edilmiştir. Bir başka önemli sonuç da sözcelerin uzunluğu kısalığ üzerinde olmuştur. Eserde genel olarak sözceler kısa ve açık tutulurken nesne betimlemelerinde 40-42 kelimeden oluşan sözcelerin varlığı dikkat çekmektedir (Örneğin 5 no'lu sözce ).

Zola'nın üslubunda nesne anlatılarının bütün eser boyunca iki önemli özelliği göze çarpmaktadır: Bunlardan ilki roman kahramanının ruh haline göre nesnenin kazandığı anlam ve şekil ki bu daha çok aynı nesne üzerindeki tezatlardan hareketle ortaya konulmuştur. İkincisi ise nesnenin anlatımında kullanılan değerlendirici sıfatların sayıca ve tekrar açısından sıklığıdır ki bu da bu tarz bir sözcelem de nesnelere okuyucunun gözünde kullanım değeri dışında bir bireysel değer kazandırmaktadır. Çalışmanın sonunda, yazınsal metinde kullanılan 
Yılmaz, S. ve Kılı̧̧, M. (2021). Klasik bir edebî romanda nesne adlarında kullanılan göstergelerin yorumlanması. Humanitas, 9(18), 342-365.

nesnelerin ve onları niteleyen dilsel göstergelerin değeri ve işlevlerinin sözcelemsel bağlama göre ne kadar çeşitli ve zengin olduğu görülmüştür. 
Yılmaz, S. ve Kılı̧̣, M. (2021). Klasik bir edebî romanda nesne adlarında kullanılan göstergelerin yorumlanması. Humanitas, 9(18), 342-365.

\section{Kaynakça}

Aksan, D. (1999). Her yönüyle dil ana çizgileriyle dilbilim (3.cilt). Ankara: Türk Dil Kurumu Yayınlar1.

Aşkın Balcı, H. (2006). Metindilbilim açısından bir çözümleme. Erciyes Üniversitesi Sosyal Bilimler Enstitüsü Dergisi, 21(1), 191-204.

Barthes, R. (1986). Göstergebilim ilkeleri (M. Rıfat ve S. Rıfat, Çev.). İstanbul: Sözce Yayınları (Orijinal çalışma basım tarihi: 1964).

Demirci, K. (2017). Türkoloji için dilbilim. Ankara: Anı Yayıncılık.

Dervişcemaloğlu, B. (2014). Anlatıbilime giriş. İstanbul: Dergâh Yayınları.

Erkman Akerson, F. (2005). Göstergebilime giriş. İstanbul: Multilingual Yayınları.

Erkman Akerson, F. (2008). Dile genel bir bakış. İstanbul: Multilingual Yayınları.

Günay, V.D. (2013). Söylem çözümlemesi. İstanbul: Papatya Yayınları.

Günay, V.D. (2013). Metin bilgisi. İstanbul: Multilingual Yayınları.

Gürün, H. (2016). Metindilbilimsel yöntem ile çözümlenen Sait Faik'in "Dülger Balığının Ölümü’nde insanın doğaya tahakkümü ve ötekileştirilmesi. Uluslararası Türkçe Edebiyat Kültür Ĕgitim Dergisi, 5(4), 1841-1882.

Kansu Yetkiner, N. (2009). Çeviribilim dilbilim ilişkisi üzerine. İzmir: İzmir Ekonomi Üniversitesi Yayınları.

Kıran, Z. (1999). Sözceleme ve göstergebilim. Dil Bilim Araştırmaları Dergisi, 10(1),93-99.

Mutluay, R. (1979). 100 Soruda edebiyat bilgileri. İstanbul: Gerçek Yayınevi.

Özkan, B. (2004). Metindilbilimi, metindilbilimsel bağdaşıklık ve Haldun Taner'in “Onikiye Bir Var" adlı öyküsünde metindilbilimsel bağdaşılılı görünümleri. Çukurova Üniversitesi Sosyal Bilimler Enstitüsü Dergisi, 13(1),167-182.

Nesne. (2019) Türk dil kurumu güncel Türkçe sözlük içinde. https://sozluk.gov.tr/

Nesne. (t.b.) Kubbealtı lugatı içinde. http://lugatim.com/s/NESNE

Pamuk, O. (16.10.2008). Masumiyet Müzesi'nin ilham kaynakları. Kültür sanat haberleri, Milliyet. https://www.milliyet.com.tr/kultur-sanat/masumiyet-muzesi-nin-ilhamkaynaklari-1003212.

Rıfat, M. (1998). XX. Yüzyılda dilbilim ve göstergebilim kuramları. İstanbul: Yapı Kredi Yayınlar1. 
Yılmaz, S. ve Kılı̧̣, M. (2021). Klasik bir edebî romanda nesne adlarında kullanılan göstergelerin yorumlanması. Humanitas, 9(18), 342-365.

Sassure, F. (2001). Genel dilbilim dersleri (B. Vardar, Çev.). İstanbul: Multilingual Yayınları (Orijinal çalışma basım tarihi: 1916).

Uçar, A. (2012). Teselliyi eşyada aramak: Türkçe romanda nesneler. (Yayınlanmamış doktora tezi), İhsan Doğramacı Bilkent Üniversitesi, Ankara.

Vardar, B. (2007). Açıklamalı dilbilim terimleri sözlügü̈. İstanbul: Multilingual Yayınları.

Yücel, T. (2015). Yapısalcılık. İstanbul: Can Yayınları.

Zola, E. (2011). Claude'un itirafları (S. Yılmaz, Çev.). İstanbul: İdeal Kültür Yayıncılık (Orijinal çalışma basım tarihi: 1909). 